\title{
Catholic Documents 101
}

\section{A Theological Librarian's Guide to Identifying, Locating, and Using the Documents of the Catholic Church}

By James Humble, St. Charles Borromeo Seminary; Kathy Harty, Sacred Heart Seminary and School of Theology; Elyse Hayes, Seminary of the Immaculate Conception; Andrew Kosmowski, University of Dayton

\begin{abstract}
The teachings of the Catholic Church are found in numerous documents, produced by different persons or groups across centuries, whose arrangement and importance relative to each other are often hard to understand. This Listen and Learn session familiarizes librarians from non-Catholic backgrounds with the various types and features of Catholic Church document, concluding with strategies for answering a sample reference question by relying on that material. By sorting through the classification of these documents and directing attendees to the most authoritative or most easily obtainable sourcematerials for those documents, this session makes it easier for librarians working in non-Catholic settings to help patrons with research questions concerning Catholic doctrine.
\end{abstract}

\section{INTRODUCTION}

Over the course of two thousand years, theologians have accreted mountains of writings on every aspect of the Christian faith. While even devoted students of Christian doctrine likely will not have time to scale all of the peaks in a single academic lifetime, they cannot afford to skip completely over one of the highest summits: the documents of the "teaching arm" of the Catholic Church, the Magisterium, which safeguards the deposit of faith and interprets controversies in light of it. Those approaching doctrinal matters, such as the atonement and the virgin birth, from a Protestant perspective may find it beneficial to 
examine the Catholic position from the mouths of those who formulated them. But how do librarians unfamiliar with the differences between papal encyclicals and papal exhortations, or between conciliar constitutions and conciliar declarations, help students journey across the Catholic theological landscape? How can they distinguish between casual and infallible statements by the pope? This session served not only to introduce librarians to the various types of Church documents and how they are put together, but to provide them with recommendations for the best versions both in print and on the web.

\section{SACRED SCRIPTURE AND THE FIVE Ds}

Sacred Scripture is the source from which all Church teachings flow. According to the Vatican II document Dei verbum (the Dogmatic Constitution on Divine Revelation), "Sacred Scripture is the word of God inasmuch as it is consigned to writing under the inspiration of the divine Spirit” (9).

If Sacred Scripture is the "what" of Catholic teaching, the Apostolic or Sacred Tradition is the "how." According to Dei verbum 9: "[S]acred tradition takes the word of God entrusted by Christ the Lord and the Holy Spirit to the Apostles, and hands it on to their successors [the Catholic bishops] in its full purity, so that led by the light of the Spirit of truth, they may in proclaiming it preserve this word of God faithfully, explain it, and make it more widely known." Sacred Tradition thus guides Catholics in interpreting Scripture.

With these descriptions in mind, the "five Ds" of Church documents are:

1. The Deposit of Faith, consisting of both Sacred Scripture and Sacred Tradition. Also collectively called Public Revelation, these teachings require the full assent of the faithful.

2. Doctrine, which is the substance of what is taught by the Church.

3. Dogma, those tenets of the faith formally defined (by either a pope or an ecumenical council) as a result of a controversy in the Church. The faithful are obliged to give assent to both dogma and doctrine, as they are directly derived from Sacred Scripture and/or Tradition. 
4. Discipline, or Church practices outside the realm of dogma and doctrine. These can change over time and may differ among the Churches (as, for example, the Latin Church forbids married men from becoming priests, while Eastern Churches allow them).

5. Devotions, or "the religious sense of the Christian people" (CCC 1674). Devotions complement but do not replace the liturgical celebrations (CCC 1675). Examples include: "veneration of relics, visits to sanctuaries, pilgrimages, processions, the stations of the cross, religious dances, the rosary, medals, etc.” (CCC 1674).

Set apart from the five Ds is private revelation, which includes apparitions (of the Blessed Mother, for example) and locutions (the phenomenon of people who transcribe what are apparently direct transmissions from Christ or a saint) that fall outside the boundaries of public revelation. The assent of the faithful is not required for these, even if the Church recognizes an apparition, say, as valid.

\section{CONCILIAR, PAPAL, NATIONAL, AND LOCAL}

Official documents of the Catholic Church have evolved over time, but commonly come from four basic sources: the popes, the ecumenical councils, the Roman Curia, and the bishops. These documents and their sources are briefly explained below.

1. Apostolic constitutions and decrees issued by popes, such as the Second Vatican Council documents. Along with Code of Canon Law (1983), these are binding on the entire Church. These documents are said to have conciliar or universal authority.

2. Papal teaching documents, which expound or explain existing law. The most common of these follow.

- Apostolic constitutions are considered the most solemn kind of document issued by a pope in his own name. Constitutions can define dogmas but also alter canon law or erect new ecclesiastical structures. An example is John Paul II's apostolic constitution Ex Corde Ecclesiae, defining the role and responsibility of Catholic institutions of higher education.

- Encyclical letters are next in importance to consitutions, 
exhorting the faithful on a doctrinal issue. Its title is taken from its first few words in Latin. An encyclical is typically addressed to the bishops but intended for instruction of Catholics at large. Most of the best-known social teachings of the Church have been expressed in encyclicals. Examples include Leo XIII's Rerum Novarum, which inaugurated Catholic social teaching, and John Paul II's Centesimus Annus, which expanded on its application for the post-Cold War world.

- Once a common papal document, decretal letters are now restricted to dogmatic definitions and (more commonly) proclamation of canonizations and beatifications.

- Apostolic letters are issued by popes to address administrative questions, such as approving religious institutes, but have also been used to exhort the faithful on doctrinal issues. Apostolic letters do not typically establish laws, but exercise the pope's office as ruler and head of the Church. Paul VI issued Octogemisa adveniens in 1971 as an apostolic letter because it was addressed to one person, Cardinal Maurice Roy.

- A declaration is a papal document that can take one of three forms: 1) a simple statement of the law interpreted according to existing Church law; 2) an authoritative declaration that requires no additional promulgation; or 3) an extensive declaration, which modifies the law and requires additional promulgation. Declarations are less common now as papal documents, but were resorted to several times by the Vatican II Council. An example is Dignitatis humanae, the Declaration on Religious Liberty.

- A motu proprio is a decree issued by the pope on his own initiative. It can enact administrative decisions or alter Church law (but not doctrine). An example is Benedict XVI's Summorum Pontificum, which relaxed restrictions on celebration of the traditional Mass.

- An apostolic exhortation is a formal instruction issued by a pope to a community, urging some specific activity. Lower in import than an encyclical or apostolic letter, an exhortation does not define doctrine. An example is John Paul II's Familiaris Consortio, affirming the meaning and role of marriage and the family. 
- An allocution is an oral pronouncement by a pope, with pastoral, not doctrinal, import. Increasingly common in the modern age, allocutions are a way for popes to exhort the faithful both within and outside the context of homilies. An example is John Paul II's 2003 homily in Rijeka, The Family Requires Special Consideration.

3. Curial documents are produced by the Roman Curia, the set of various bodies (like Congregations) which are concerned in some manner with the governance of the Church. For example, instructions are issued by Congregations with the approval of the pope.

- Traditionally, Church councils have issued documents only in the form of decrees or constitutions. The Fathers of Vatican II, however, intended a pastoral rather than a strictly doctrinal council, and as a result issued a number of different kinds of documents, all promulgated under the pope's name and therefore taking the same name and form as papal documents. The highest form of document was the constitution, of which there were four (for example, Gaudium et Spes, the Pastoral Constitution on the Modern World). Ten other documents were issued as decrees, addressing specific issues within Church life (for example, Unitatis Redintegratio, the Decree on Ecumenism). Finally, three documents were issued as declarations, fairly brief documents (for example, Dignitatis Humanae, the Declaration on Religious Liberty).

- Instructions are statements issued by a Congregation, always with the approval of the pope. They are usually intended to explain or clarify documents issued by a council or decrees by a pope. An example is Donum Vitae, issued by the Congregation for the Doctrine of the Faith, clarifying Church teaching on the respect due in law for human life in its earliest stages.

- A recognitio supplies the acceptance by the relevant office of the Holy See of a document submitted to it for review by a local conference of bishops. Such acceptance is required for such conference documents to modify universal law. A recognitio thus gives conference documents legislative effect.

- Replies to dubia are official responses to questions (dubia) of bishops addressed to the Holy See seeking clarification on 
statements of doctrine or discipline. Dubia are addressed to congregations having jurisdictions. An example is the Letter Concerning the Congregation for the Doctrine of the Faith (CDF) Regarding Ordinatio Sacerdotalis, confirming that the latter document's affirmation that the Church does not have the authority to ordain women to the priesthood belongs to the deposit of the faith.

4. The official documents issued by a national conference of

bishops, usually called "pastoral letters," are explanations of how Church teaching applies to or is to be put into effect within a given country. National bishops' conferences were formally established by the Vatican II (Christus Dominus 38). Bishops' conferences issue pastoral letters, explaining how Church teaching is to be put into effect in the relevant country. To have authority, however, such letters must be consistent with the teaching of the universal Church; they must also receive official confirmation from the Holy See by means of a recognitio from the relevant curial office.

5. Pastoral letters issued by a local bishop for his diocese. Statements issued by an individual bishop only have authority within that bishop's diocese, and only provided that such statements do not conflict with the Church's universal law and teaching.

The level of magisterial authority pertaining to each type of document-particularly those of the pope-is no longer always self-evident. A Church document may (and almost always does) contain statements of different levels of authority commanding different levels of assent, or even observations which do not require assent as such, but still should command the respect of the faithful. The Second Vatican Council, speaking through Lumen Gentium (the Dogmatic Constitution on the Church) 25, identified as many as four different kinds of authority.

Msgr. Fernando Ocáriz Braña, Vicar General of Holy Cross, recently clarified this hierarchy of authority in an article in L'Osservatore Romano, the "semi-official" periodical of the Holy See: "Documents of the Magisterium may contain elements that are not exactly doctrinal-as is the case in the documents of the Second Vatican Councilelements whose nature is more or less circumstantial (descriptions of the state of a society, suggestions, exhortations, etc.). Such matters 
are received with respect and gratitude, but do not require an intellectual assent in the strictest sense (cf. Instruction Donum Veritatis, nn. 24-31)" (Fernando Ocáriz Braña, “On Adhesion to the Second Vatican Council,” L'Osservatore Romano, Dec. 2, 2011).

\section{PRINT AND WEB SOURCES}

Certain Church documents are central to anyone researching or studying Catholic doctrine. The most familiar and accessible of the print resources are:

1. The Catechism of the Catholic Church, 2nd ed. (Libreria Editrice Vaticana, 2000), which presents a summary of Catholic doctrine for non-specialist audiences. This is a totally redrawn version of two predecessors: the Roman Catechism of 1566, and the Baltimore Catechism of 1884. This contemporary version organizes its material around several established frameworks: the Apostle's Creed, the seven sacraments, the Ten Commandments, and the Lord's Prayer.

2. The Christian Faith in the Doctrinal Documents of the Catholic Church, 7th ed., edited by Jacques Dupuis (Alba House, 2001), which collates relevant passages from Church documents according to subject matter. This sets it apart from:

3. Heinrich Denziger's Compendium of Creeds, Definitions, and Declarations on Matters of Faith and Morals (Ignatius, 2012). First published 1854, now in its 43rd edition, this is a chronological arrangement, with the original language and the English translation lined up in double columns, using a paragraph numbering system that is frequently cited but which is rivaled by the Neuner-Dupuis numbering system. Because these two are so frequently used, the Dupuis volume provides the Denziger number next to its own paragraph numbers.

4. Tanner's Decrees of the Ecumenical Councils, 2 vols. (Sheed \& Ward, 1990), also arranges its title material chronologically rather than thematically, making this a source for more advanced researchers who want the complete texts in their original Latin.

5. The Liturgy Documents, 2 vols. (Liturgy Training Publications, 2004), and the Compendium of the Social Doctrine of the Church 
(Libreria Editrice Vaticana, 2004) are two examples of collections of documents pertaining to specific areas of practice and discipline.

6. The Papal Pronouncements: A Guide, 1740-1978, by Claudia Carlen (Pierian Press, 1990) is an annotated index of all the speeches, articles, interviews, and other public pronouncements made by modern popes.

Among the web resources, the most useful for finding complete texts are:

1. The Holy See (http://w2.vatican.va/content/vatican/en.html): the Vatican's website contains the full text of all the Papal, conciliar, and Curial documents of the modern era (from Pope Leo XIII on), as well as many documents of older vintage (although some of these are not available in English translations).

2. United States Conference of Catholic Bishops (http://www.

usccb.org): this website contains the documents produced by the American bishops in response to historical and cultural developments of the last century. It also includes the complete texts of both the latest version of the NAB translation and the Catechism.

\section{SAMPLE REFERENCE QUESTION}

The presentation concluded with a practical application of these materials to a reference question not unlikely to be asked in a non-Catholic environment: "Why do Catholics pray to saints? What does the Church teach about saints and their veneration?"

Among other strategies, it was suggested that librarians start with the Catechism, because of both its brevity and directness in expressing Catholic doctrine, and its constant recourse to primary documents, from Scripture through the Church Fathers to the councils, making its footnotes a handy locator for particular Church teachings. Librarians were also urged to discourage their patrons from using Google at first, since certain results for contentious questions might ignore the foundational documents altogether. 